\title{
Getting Serious About Achieving the Millennium Development Goals in the Pacific:
}

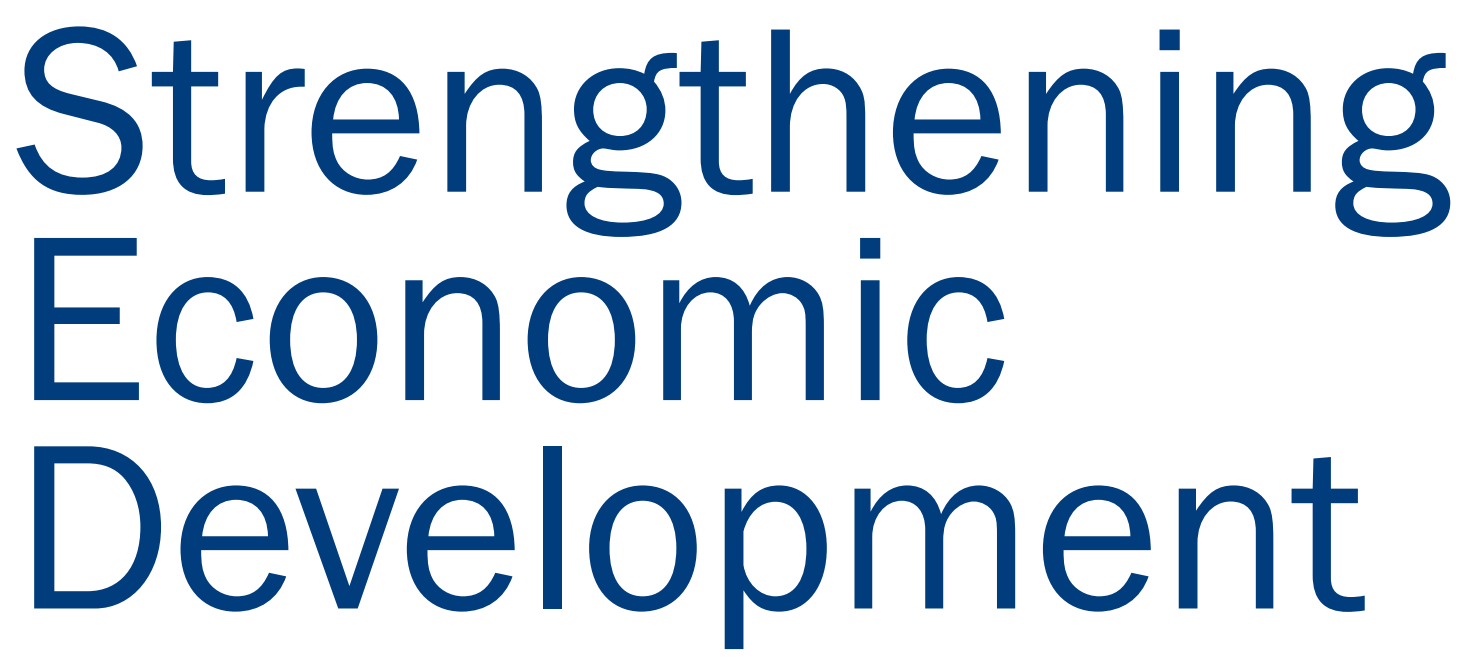

The Pacific has huge potential and a richness of natural, social and human resources that should assure a bright future. However, in the short term the Pacific's problems are mounting. The legacy of conflicts over recent years continues to affect countries, including Solomon Islands and Tonga, and Fiji is suffering a serious downturn as a result of the coup and declines in its sugar and clothing exports. Meanwhile, the global financial crisis is likely to worsen, and swine flu is likely to further curtail travel and tourism. High food and energy prices continue, and the impacts of climate change are becoming more evident and more serious.

The result of these challenges is that, on a population basis, most of the Pacific's people are suffering, and there is a serious threat that the situation will worsen. The depth of suffering being experienced extends well beyond 'hardship', the term commonly applied to the lives of those in the Pacific who have little cash income and few opportunities and lack basic services such as health care, education, clean water and sanitation (Abbott and Pollard, 2004).

The uncomfortable fact is that a large proportion of the Pacific's people live without the basic rights and opportunities that should be assured to all people in the world. The statistics reveal that around four million of the Pacific's people, almost half of the total population living in the Pacific, are living in poverty, and vulnerable people, particularly women and children, are suffering and dying because of it. ${ }^{1}$ Nearly 18,000

Barry Coates is the Executive Director of Oxfam New Zealand. children die each year in the Pacific, many of them from preventable causes. There are around one million children out of school, growing numbers of people with HIV/AIDS and, of the ten countries in the world with no women in Parliament, five are in the Pacific (AusAID, 2008).

Facing up to these challenges will require an extraordinary commitment from governments, civil society, the people of the Pacific, the Pacific's neighbouring countries and the international community. This paper sets out some of the key challenges to be overcome and suggests priorities for focus.

\section{Progress and challenges}

The framework provided by the Millennium Development Goals (MDGs) has been endorsed regularly by Pacific Island leaders as a guide to help countries to reduce poverty and improve human development since it was agreed by all nations at the September 2000 Millennium Summit. The framework is supported by the activities of the United Nations agencies in 
the Pacific, particularly the United Nations Development Programme (UNDP) Pacific Centre, the Pacific Islands Forum Secretariat, the Secretariat of the Pacific Communities and other regional agencies.

Despite international acceptance by governments and considerable support from civil society, the MDGs have been subject to criticism for their approach, in particular for ignoring some of the key underlying determinants of well-being, such as family and societal cohesion, putting too much attention on the role of the state and services such as health and education while neglecting the importance of economic development and the private sector, and ignoring issues that are crucial to human rights, such as violence against women.

Of particular concern for the Pacific is that the MDG's headline measure of poverty, the threshold of US\$1 per day, focuses on the cash economy. This largely excludes the contribution of women, and production for subsistence use, which is the main source of livelihood for many in the Pacific. The emphasis on quantifying the components of development in order to count them can distort priorities. Not everything that can be measured counts; and not everything that can be counted is valuable.

While these are valid criticisms, it should also be recognised that the MDGs have proven to be an important rallying point for focusing action on the needs of the poor, and for tracking the degree to which their lives are improving (DFID, 2009). The MDGs have played an important role in focusing the attention of government policy and aid donors onto the lives of people who are disadvantaged, rather than the political interests that have often dominated government priorities and aid spending.

In addition, contrary to common perception, the MDGs are not a universal and inflexible framework, but are intended to be modified to suit the circumstances in different regions and countries. Accordingly, most Pacific Island countries have now adapted and integrated the MDGs into their national development processes, or are in the process of doing so, and many have reported on progress.

A regional report on MDG progress covering all 15 Pacific Island countries was compiled in 2004 and, as at the end of 2007, eight Pacific Island countries had produced national MDG reports, with a further six in various stages of completion. As progress reports show, much of the Pacific is off-track on the targets for achievement of the MDGs, particularly the Melanesian countries, which account for around 90\% of the Pacific's population. The 2005 UN report on progress against the MDGs highlighted that two regions in the world are falling furthest behind in meeting the globally-agreed 2015 Millennium Development Goals: subSaharan Africa and Oceania (Pacific). The report concluded: 'only sub-Saharan Africa is off-track with more indicators than Oceania' (UN, 2005).

These reports need to be put into context. ThePacificincludesconsiderable diversity and some countries have made great strides towards meeting the MDGs. On a population basis, the overall data ${ }^{2}$ is dominated by a group of large, lowincome states (Papua New Guinea, Solomons Islands and Vanuatu). They are characterised by high population growth, most people living in rural areas with semi-subsistence livelihoods, low levels of income, little formal education and poor health indicators.

Socio-economic indictors are higher for some of the island states (the Federated States of Micronesia, Kiribati, Nauru, the Marshall Islands and Tuvalu), especially those that have associations with developed nations. However, these states are typically dispersed across huge tracts of ocean, crowded, urbanised and highly vulnerable to natural disasters and the impacts of climate change.

A third group is the more economically advanced island states (Cook Islands, Fiji, Palau, Samoa and Tonga). They have relatively high levels of income and social well-being, high levels of remittances and opportunities for migration to developed countries. They are on track for most of the MDGs.

Another useful indicator of development is the UNDP's annual Human Development Report. In the 2008 report, Tonga (ranked 55th out of 177 countries) was the only Pacific Island country to be included in the listing of countries enjoying a high level of human development, but the data has yet to include the full impact of the Nuku'alofa riots that destroyed much of the city centre. The rest of the Pacific received grades that placed them with 'medium' levels of human development: Samoa (77th), Fiji (92), Vanuatu (120), Solomon Islands (129) and Papua New Guinea (145). ${ }^{3}$ While most countries have improved on the key indicators, the Pacific's rate of progress has been slower than that of other regions. All those Pacific countries, with the exception of Samoa, have fallen down the rankings over the past decade (UNDP, 2007).

It is not widely understood that some Pacific countries rank amongst the most unequal societies in the world. Although data is patchy, the gaps between rich and poor appear to be widening. For example, measured by the Gini coefficient (the accepted measure of inequality), Vanuatu is perhaps the most unequal country in the world (Bazeley and Mullen, 2006). The Gini coefficient estimate for PNG is only slightly better (AusAID, 2001). ${ }^{4}$

The World Bank has documented one of the ways in which inequality is perpetuated, showing that the numbers of outof-school children from poorer households is far higher than from the richest households. This is consistent with Oxfam's 
experience, in that the cost of school fees is a recurring reason given for the high level of 'push-outs', particularly in Melanesia. As a result, the greatest inequities are for attendance at secondary school where fees are significantly higher than at primary schools. The enrolment rate for the highest quintile income in Vanuatu, for example, is $50 \%$, compared to $15 \%$ for the lowest quintile (World Bank, 2007).

\section{Building on the Pacific's strengths}

In analysing the way forward for the Pacific to improve the well-being of its people, it is important to establish priorities based on where people live in hardship and suffering, but perhaps even more importantly to start with understanding the Pacific's strengths. This is important because much of the media coverage of the Pacific in recent years has highlighted incidents of conflict and violence, social problems and natural disasters. In addition, much of the academic research (notably Hughes, 2003) has focused on the Pacific's perceived failings, including conflict, poor governance, low level of exports and weak private sector development. By contrast, the literature of a number of Pacific academics and researchers highlights the Pacific's uniqueness and its strengths (Hau'ofa, 1993).

In reality the Pacific is a region containing a wealth of marine and other natural resources; rich culture, knowledge and traditions; and capable and resourceful people. PNG civilisation is over 50,000 years old, and it is likely that their people were the world's first agriculturalists, developing sophisticated forms of sustainable agriculture over the centuries. Polynesian explorers built sailing vessels that were considered to be faster than any others in the world at the time. And Pacific communities have developed enormous resilience based on access to land, a strong cultural identity and systems of community governance.

The strength of communities in Melanesia means that the countries are sometimes referred to as 'nations of villages'. Resilience is supported through the sharing of communal resources and cultural obligations to look after others. The desire or ability of communities to unite to ensure accountability or make coordinated demands on leaders is in some ways hindered by the fragmentation of societies along language, clan and cultural lines - for example, via the wantok system in Melanesia. However, the innate strengths of this system, around family, collectivism and reciprocity, also provide many opportunities for identifying and building on traditional mechanisms for accountability and good governance.

The Pacific contains most of the world's remaining tuna fisheries and other potentially highly valuable marine resources. Its countries are spread over 30 million square kilometres of ocean and have exclusive economic zones covering 20 million square kilometres. Its 530,000 square kilometres of land include productive agricultural land, valuable minerals, old growth forests, high levels of biological diversity and areas of outstanding natural beauty.

There is also huge strengthin the Pacific's overseas communities, concentratedin New Zealand, Australia and the West Coast of the United States, some of them far larger than the populations back home. Not only do migrants from the Pacific retain strong links with and send remittances home, but they also play far broader roles in forging links between the Pacific and the rest of the world. Those who retain close links with their homelands become the people who live neither solely here not there, but in both places simultaneously. They can play a vital role in building the social and economic connections between the Pacific and their richer neighbours.

\section{What kind of economic development?}

The issue of economic development is crucial to the Pacific's future and high on political agendas in New Zealand, Australia and Pacific Island countries. The new National-led government in New Zealand has changed the mandate for the government aid agency, NZAID, to 'support sustainable development in developing countries, in order to reduce poverty and to contribute to a more secure, equitable and prosperous world', and specified that the core focus within that mission be the pursuit of sustainable economic development (New Zealand Cabinet, 2009).

The issue of economic development is also high on the list of priorities for Pacific governments, as has been clear from the strong focus on economic development in the Pacific Plan. While it is often interpreted as being a job for the private sector, stimulating economic development is also a key priority for many civil society organisations, including Oxfam and many of our partners and allies across the Pacific.

\section{Learning from the past}

The patterns of development experienced by today's developed and emerging economies provide insights into how countries have successfully increased their standard of living and reduced poverty.

The weight of evidence and academic research now recognises that the pursuit of economic growth as an aim without addressing the equitable distribution of the benefits, or the participation of those who are disadvantaged, fails to build the conditions for long-term development. Not only does it fail to produce a middle class which can provide internal markets, but growth without equity creates social and political tensions that are likely to destabilise societies 
and exacerbate conflict between different groups within society (Collier, 2007). The pursuit of growth without equity elevates self-interest above the broader interests of society, fostering corruption and a lack of accountability (Green, 2007).

Levels of inequality in the world have increased sharply over recent decades. There have been economic theories that have regarded such inequalities as an inevitable outcome of development processes, or even helpful. These have often been characterised as 'trickle-down' economics, so called because the theory suggests that once wealth has been created it will trickle down to the poor.

Structural adjustment programmes and other reforms to promote market growth have resulted in limiting the role of the state in the economy, on the assumption that the market would operate more efficiently. This has meant massive reductions in support for the agricultural sector, the virtual collapse of agricultural extension services, withdrawal of support for agricultural information and ending of support for smallholder marketing. These impacts are evident in the Pacific, as well as in other regions, including as a result of Vanuatu's Comprehensive Reform Programme (Bazeley and Mullen, 2006).

From a development perspective, these forms of development have channelled resources away from the poor and caused unnecessary suffering. The lack of development for a large number of people in the economy has resulted in high under-employment and wasted the skills and capabilities of much of the region's population. The costs have been particularly severe on small farmers, and those in society without the education, assets and capabilities to benefit from unregulated markets. This undermines the purpose of most governments and aid donors, who have explicit aims to support those who are poor and disadvantaged.

Perhaps the most persuasive argument against the pursuit of growth per se is that evidence shows that growth with equity is more successful. The countries that have targeted the needs of the poor and enabled them to participate in the development process have done better. There are stark contrasts between the relatively equal societies of East Asia and the deep inequalities in many Latin American and African countries. Equality is not only good for poverty reduction, it is good for growth (Green, 2007).

These findings are particularly relevant for small and vulnerable economies. Long-term evaluations and studies of the structural adjustment programmes that were strongly pushed by the World Bank, Asian Development Bank and others from the mid-1980s produced evidence showing that markets in small and immature economies do not work in the ways that

are predicted by economic models. In the terms used by economists, they are prone to widespread market failures. Such failures are endemic in small economies with immature markets, weak institutions, undeveloped regulatory systems and capacities and poor governance. These characteristics apply to a number of Pacific Island economies.

With mounting evidence of the failure of market fundamentalism (even before the global financial crisis), the international institutions have been re-thinking the appropriate economic development models. However, despite significant changes in the development discourse, little has yet changed in terms of the policy dialogue between the international financial institutions and governments. This was characterised in a recent article by Harvard academic Dani Rodrik as 'goodbye Washington consensus, hello Washington confusion' (Rodrik, 2006).

There has been a revival of interest in economic history as a way to understand development processes. The Cambridge University economist Ha-Joon Chang has revealed the degree to which OECD countries and the Asian tigers used well-designed government intervention in their economies during their development phase (Chang, 2002). Chang also highlights the degree to which today's developing countries are precluded from using such policies through trade agreements.

Meanwhile, the policy conditions required for growth have come under closer scrutiny. Analysis of the experience of developing countries has shown that there is no evidence that trade liberalisation leads to economic growth, but there is evidence that countries that are successful in economic growth then open up their economies (Rodrik, 2004). This is an important difference and suggests that the advice given to small and vulnerable Pacific states by donors and international institutions needs to be questioned. An implication is that well-designed government intervention in the economy can be important in boosting exports and international competitiveness and Pacific countries should not be precluded from using such policies in future (Coates and Lennon, 2005).

In summary, there is considerable evidence that the pursuit of growth per se is likely to exacerbate inequalities and be less successful than the pursuit of economic development that is specifically targeted to benefit the poor (often termed 'growth with equity', 'pro-poor growth' or 'broad-based economic development').

impact on society,

it is useful to

derive principles

that can guide

the development

priorities.

\section{Strategies for economic development Principles for economic development for the Pacific}

Since not all economic development is alike in its ability to benefit those in poverty and in its impact on society, it is useful to derive principles that can guide 
the development priorities. These may differ across different Pacific societies and contexts, but the following principles are a starting point:

- sustainable - environmentally, socially, culturally, economically and financially;

- broad-based - with equitable distribution of the benefits, including for women and disadvantaged groups;

- appropriate - to the culture and situation (no 'one size fits all' approaches);

scaleable - to the Pacific's resources and needs.

A far longer list could be generated, incorporating a more comprehensive range of principles, but the above list provides a useful lens through which to assess the appropriateness of different forms of economic development and the challenges in re-directing much of the current development.

There are clearly some current economic activities with rates of extraction that are highly environmentally unsustainable (mining, logging, fisheries) and others that fail to meet the social sustainability and equity tests. The interrelationship between these factors is shown by the recent financial difficulties of the Solomon Islands government, at least partly a result of a sharp reduction in logging exports.

A lack of sustainability in the use of natural resources, including land, has the potential to trigger conflict. Most significantly, a complex mix of factors, including dissatisfaction with the share of economic benefits for landowners and growing environmental damage, combined with unequal development between groups to trigger the crisis at the Panguna mine and precipitate a decade of conflict in Bougainville.

It should also be recognised that land has significance for Pacific peoples that extends far beyond its economic value. There is considerable pressure for changes to customary land tenure through 'land reform' or 'land mobilisation' in order to provide collateral for loans and open the way for new resource or tourism projects. However, there are risks of alienation of land from traditional owners and their children, including through the sale of land as real estate to foreign buyers, a trend that is alreadycausing deepconcern in Vanuatu. This is unlikely to generate sustained economic development or livelihood opportunities, especially not for youth. In addition, the issues of land are perhaps the most potent of conflict triggers and land disputes have played a central role in many of the conflicts in the Pacific.

Unfortunately, there are few opportunities for Pacific people to debate and decide on what forms of economic development they would like to see in their countries in the future. The process to develop a Pacific Plan in 2004-05 could have provided such an opportunity, and many countries held consultations. However, these were generally limited in scope and involved few participants. As a result, there has been little broad-based acceptance of the Pacific Plan or the directions that it sets for the Pacific.

Another important opportunity should occur during the lead up to negotiations on the Pacific Agreement on Closer Economic Relations (PACER) between the Pacific Island countries and New Zealand and Australia. The Pacific has proposed a period of research, analysis and consultation that would enable them to determine their interests and policy priorities in negotiations. New Zealand and Australia should support this important stage on the negotiations roadmap.

The above principles can serve as a guide to assess whether a particular form of economic development is likely to contribute to overall welfare. However, there are also business realities that need to be taken into account that determine what kinds of economic development may be feasible. The Pacific has inherent disadvantages, such as small economies of scale, a long distance to major markets, a lack of an existing supplier base, limited skills and experience in most manufacturing and service sectors and poor business infrastructure.

These disadvantages combine to produce a 'price' for smallness and remoteness. Empirical studies (Winters and Martins, 2004) show higher costs for transport, utilities, wages and rents for producers in small island states. Given that these producers are generally small participants in world markets, and are unable to influence prices, they are unable to pass on these costs to consumers. This means that large segments of cost competitive production are uneconomic for small island states, such as the supply of commodity products at low margins. These disadvantages are well known to the small businesses and entrepreneurs across the Pacific as they struggle to gain a foothold in competition with far larger competitors that do not suffer from them.

It is vital, therefore, that the Pacific understands not only the broad basis of comparative advantage (the differences in costs for factors of production) but their position with regard to the competitive drivers that affect different market segments. Businesses and producer organisations in the Pacific will have opportunities to succeed where the Pacific's inherent characteristics can be used as advantages rather than disadvantages. This is crucial in providing new opportunities for the Pacific to provide jobs for its youth and build an economic base for its future. Some of the areas where Pacific 
producers can sustain a competitive position include:

- niche markets for agricultural products (organics, fair trade, differentiated products);

- agricultural production for the domestic market (including supply for hotels and tourism) and small-scale import substitution;

- sustainable use of natural resources, with higher levels of value added and local benefits (joint management of tuna fisheries, environmentally certified timber, use of biological diversity);

- high-value tourism (eco-tourism and village-based tourism);

- arts, culture and sports;

- temporary labour schemes linked to skills training and community investment.

There are already exciting initiatives underway across the Pacific under each of these approaches, but far more can be done to build on these initiatives (Coates, 2009). One of the major challenges is to provide the policy framework and infrastructure that will most effectively support sustainable and equitable forms of economic development.

\section{Infrastructure}

Recent policy changes in New Zealand and Australia have identified an increased role for bilateral aid programmes in funding physical infrastructure. Some other donors, notably China and Japan, are already heavily focused on sports stadiums and other public facilities, roads and bridges.

There are clearly urgent infrastructure needs in order to support economic development initiatives (World Bank, 2006). Producers need to get their produce to market at reasonable prices and are often unable to do so at present. Enterprises need finance, whether from credit unions, remittances, banks or credit facilities. Producers need communications, electricity, water and waste disposal. However, in other cases it is human capital that is the binding constraint on development.

\section{Education and vocational training}

Economic development needs skilled workers and management. Despite high levels of unemployment and even higher levels of under-employment, many enterprises in the Pacific struggle to find skilled and reliable workers and managers. The high numbers of expatriates in many Pacific countries bears testimony to the shortage of professional staff and skilled management.

In most of the Polynesian countries, there is universal (or close to it) access to primary education and high levels of completion of secondary education. However, this is by no means the case in the Melanesian countries. Even where there has been progress towards universal primary education, many of the children who enrol do not complete primary school (e.g. 54\% in PNG). Overall, only 33\% of children of secondary school age in the Pacific in 2006 were in secondary school, while $6 \%$ were still in primary school and $62 \%$ were out of school - the highest rate out of school for any region worldwide (UN, 2008). Further, the quality of education is problematic. A recent literacy survey in Vanuatu found that $27 \%$ of Year 6 students could not write a simple dictated sentence (AusAID, 2008).

There are a number of promising initiatives underway to provide education for all the Pacific's children and improve the quality of education. These include government programmes, aid donor programmes (such as the NZAID sectorwide approach in Solomon Islands) and a range of civil society and community-based initiatives (including the 48 rural training centres in Vanuatu supported by Oxfam).

However, without basic skills, it is hard to see how economic development can take place, other than as a series of 'enclave developments' that benefit the few and leave most of the population outside the formal sector. Therefore, particularly for the Melanesian countries, education and vocational training should be seen as a vital component of economic development, no less important than roads or bridges.

\section{Human health}

It is clear that people cannot work if they are sick. However, the indirect impacts of human health are not so well understood. Pacific countries (particularly the Melanesian countries) typically have relatively high levels of illness and disease, poor public health services and highly expensive private services, if these are available at all. Therefore, absenteeism or withdrawal from the workforce is often necessary in order to take care of a sick partner, parent or neighbour. Even if that person is able to work, their productivity is also adversely affected by hunger, weakness due to previous bouts of disease or malnutrition, or persistent and recurring illnesses such as malaria, respiratory diseases, worms or diarrhoea.

Therefore, a focus on infrastructure to support economic development should use a broader definition than the commonly used focus on physical infrastructure. As well as serious gaps in transport, communications and utilities, there are also serious constraints in the human infrastructure that is needed to support economic development.

\section{The role of those outside the Pacific}

The preceding sections have set out some of the challenges for the Pacific if it is to achieve the level and types of economic development that will make a serious difference 
in ending poverty. While the primary responsibilities and impetus need to come from the Pacific, others have a role to play. In particular, the Pacific Islands' neighbours, New Zealand and Australia, can have a major influence on the future.

Their influence derives not only from support through development assistance, but also through the impact of their policies on the Pacific. All too often in the past, the benefits of aid given with one hand have been taken back, and more, with the other. Government policies towards the Pacific need to be coherent.

\section{Development assistance}

Australia and New Zealand are key donors to the Pacific, with Australia providing around half of all official aid. The level of aid has risen over the past decade to US\$1.1 billion in 2006, but has barely risen in per capita terms over this period. Both Australia and New Zealand have announced increases to their aid levels and a focus on the Pacific. While such increases are welcome, aid from both countries remains well below the UN target of $0.7 \%$ of gross national income that donor countries have committed themselves to attaining by 2015 .

There is an international process for aid effectiveness that aims to strengthen donor coordination. Australia and New Zealand are already taking practical steps to strengthen coordination and collaboration, and the UN agencies are moving towards a 'one UN' approach. However, coordination with countries such as China is far weaker. At a time when Australia and New Zealand have suspended aid to Fiji as a result of the coup, China has increased its aid from US\$23 million to an estimated US\$160 million in 2007 (Hanson, 2009).

The international aid effectiveness agenda, coordinated through the OECD, has provided a useful reminder to donors that country ownership of aid is important for the implementation of policies and programmes and their longerterm sustainability. However, there are important aspects of development effectiveness that are not included in the aid effectiveness agenda, including the potential sidelining of issues such as gender rights, which may not be a priority for developing country governments.

In particular, the aid effectiveness agenda largely ignores the role of civil society. This is a major problem in countries and regions (such as much of the Pacific) where the legitimacy of the state is challenged, where there is weak state delivery of services and where the state is insufficiently unaccountable to its people. In such situations, often characterised as 'fragile' states, a significant role is played by structures such as the churches, traditional leaders' forums and nongovernmental organisations. Operating effectively in such countries represents a challenge for aid agencies, since almost all of their aid is delivered through government-to-government programmes or intergovernmental regional or multilateral programmes.

The role of civil society is not only to act as an alternative delivery mechanism to get essential services to remote and marginalised communities, but also to build economic development from the grassroots. Communities are obviously concerned about the lack of education, health care, water supply and other services, but they also lack the delivery of government support services for important economic functions such as agricultural extension, advice on product standards, organisation of local markets and business development.

Further, the weakness of states is often closely linked to the absence of citizen voice and participation (Sen, 2008). Civil society has an important role to play in building the capacity of communities and local organisations to press for accountability and the delivery of services by governments. Donor governments may impose conditions for the delivery of services (under Sector Wide Approaches, for example), but these are unlikely to be effective unless there is a complementary 'bottom-up accountability' from civil society and community-based groups.

The role of governments in supporting public sector delivery has also come under close scrutiny from researchers and academics. There has, for some time, been a critique of aid as ineffective, particularly citing the growth of the public sector and the relative weakness of the private sector (Hughes, 2003), but a recent paper from the Lowy Institute (Hayward-Jones, 2008) has again gained the attention of politicians in Australia and New Zealand. The paper recognises the potential for growth of the informal sector and the rural economy, including through programmes working with civil society, supporting small business and developing microfinance. However, much of the focus is on reforms that are required to promote a business-friendly environment, including the factors scored in the World Bank's survey on ease of doing business, rather than on a closer examination of the more fundamental reasons for low levels of domestic and foreign investment in the Pacific.

The increased focus of aid programmes, such as New Zealand's, on economic development in the Pacific is timely, particularly since it is a means to support sustainable development in developing countries in order to reduce poverty, rather than as an end in itself. However, the way this is operationalised and measured is important. While NZAID's policy on economic growth and livelihoods has developed outcomes that focus on the poor, ${ }^{5}$ the high-level indicators used for development assistance by the Ministry of Foreign Affairs and Trade focus on unconditioned economic measures: GDP per capita, balance of trade and ratings for 'ease of doing business' (MFAT, 2009). These provide little 
guidance on whether or not most of the populations are benefiting, whether sustainable development is supported or whether poverty is being reduced.

\section{Trade}

Trade can be a powerful mechanism for the reduction of poverty if the rules that govern trade are fair (Oxfam, 2002). Trade policies of the New Zealand government should not undermine its efforts to promote economic development and the achievement of the MDGs in the Pacific.

The major problems facing Pacific exporters are typically not a lack of access to markets, but the lack of capacity amongst producers and exporters to meet the high standards of quality and reliability that are required to export to New Zealand and other markets.

There are also avoidable non-tariff barriers and restrictive rules of origin that are more directly a result of New Zealand's policies and practices. The government could also do more to enable Pacific countries to meet New Zealand's sanitary and phyto-sanitary regulations and food safety standards, and improve rules of origin to match those New Zealand provides to a number of other trade partners. These constraints are not only theoretical. They put Pacific producers at a significant cost, quality and price disadvantage. If New Zealand is serious about supporting economic development in the Pacific, these trade barriers could be lowered in advance of trade negotiations with the Pacific.

Over the past five years, the Pacific has been involved in a long and difficult trade negotiation with the European Union. As a result, the major Pacific exporting countries had little choice but to accept agreements that would maintain their export markets - PNG to protect their canned tuna exports to the EU, and Fiji to protect sugar exports. The negotiations left the Pacific with no illusions that the negotiations were about promoting development, despite undertakings in the Cotonou Partnership Agreement between the countries of Africa, the Caribbean and the Pacific with the EU.

The June 2009 Pacific trade ministers' meeting in Apia has recommended the start of negotiations with Australia and New Zealand under PACER. Civil society organisations in the Pacific, supported by Oxfam and others, are calling for the negotiations process to ensure that Pacific governments have sufficient time, information and support to be able to consult fully with their people prior to commencing negotiations on issues that are likely to shape their economic future for decades, even generations to come.

The New Zealand government has undertaken to ensure that any agreement will not be a 'free trade agreement' framework, but will have the aim of promoting sustainable development and poverty reduction. This is welcome, but needs to be reflected in all aspects of the negotiations process, including providing the time and capacity for Pacific governments to consult widely and negotiate effectively (Braxton, 2009).

\section{Climate change}

There is a clear international consensus amongst climate scientists and world leaders that climate change is occurring and that it is caused by human activity. The impacts of climate change are already hitting vulnerable communities. The Inter-governmental Panel on Climate Change (IPCG) is very highly confident that: 'Physical and biological systems on all continents and in most oceans are already being affected by recent climate changes'. Climate change is already affecting permafrost, water resources, coastal zones and oceans. Although human effects are harder to discern, due to the impact of non-climatic drivers and adaptation, the IPCC has some confidence that climate change has already affected forestry and agricultural systems and the human health system.

A recent report from the Global Humanitarian Forum, released by Kofi Annan and peer reviewed by leading scientists, documented the current impacts of climate change: 325 million people seriously affected, annual deaths of 300,000 people and economic losses of US\$125 billion (Global Humanitarian Forum, 2009). These will significantly worsen if emissions are not cut deeply and urgently.

Climate change impacts on the Pacific will affect all aspects of the Millennium Development Goals. If climate change is not checked, some islands in Kiribati, Tuvalu, Vanuatu and parts of Papua New Guinea and the Marshall Islands are likely to become uninhabitable. Their residents will need to be evacuated, and will lose their land, homes and livelihoods. Islands that remain habitable will face increased vulnerability to flooding, water shortages and contamination, cyclones and disease (Oxfam New Zealand, 2009).

As close neighbours of the Pacific Islands, New Zealand and Australia bear a special responsibility
Even if

temperature increases are kept below $2^{\circ} \mathrm{C}$ there will be major, often devastating impacts on the lives of the poorest people and on poorer countries. to take action on climate change. Yet they have been two of the countries that have failed to commit adequate offers into the current UN negotiations.

The New Zealand minister for climate change negotiations, Tim Groser, has signalled that overall greenhouse gas concentrations may need to be stabilised well below 450ppm. This is welcome, but New Zealand is late with submitting its target for medium-term emissions reductions to the UNFCCG negotiations. Oxfam and many civil society organisations (including the international Climate Action Network) are calling for Annex 1 countries to reduce emissions by at least $40 \%$ by 2020 in order to ensure that global temperature rises remain well below $2{ }^{\circ} \mathrm{C}$. 
Even if temperature increases are kept below $2{ }^{\circ} \mathrm{C}$ there will be major, often devastating impacts on the lives of the poorest people and on poorer countries. As an example, with this level of warming as many as 1.8 billion people could be affected by water stress due to shrinking water availability, including those in many small island states. The Alliance of Small Island States (AOSIS) is therefore calling for a global commitment to keeping temperature rise to below $1.5^{\circ} \mathrm{C}$, because the projected impacts of a $2{ }^{\circ} \mathrm{C}$ rise on low-lying island states is unacceptable.

Oxfam estimates that at least US $\$ 50$ billion annually is needed to support adaptation in developing countries $(O x f a m$, 2008). Developed countries must provide these resources as compensatory payments - not as loans - to address the costs of past pollution. Support for developing countries to adapt to climate change should not come at the expense of urgent development priorities under New Zealand's aid programme, thereby reducing support for health care, education, clean water and economic development.

Current funding for adaptation in developing countries is less than $1 \%$ of this level, and less than a single state in Germany is spending on flood defences (Global Humanitarian Forum, 2009). A dedicated adaptation finance mechanism should be established as an integral part of the post-2012 climate regime. The mechanism would ideally build on the principles, experiences and governance structures of the Kyoto Adaptation Fund, as it provides a fair and appropriate level of representation of developing countries.

It is unlikely that funding will be available from recurrent government budgets. A new form of financial instrument will be needed to deliver the funding required. Oxfam believes the most promising options for raising the needed finance would be to auction a fraction of emissions allocations (AAUs) provided to developed countries under a post-2012 agreement, and to set up emissions trading schemes for both international aviation and shipping.

It is vital that action is taken by those outside the Pacific on climate change. The countries and peoples of the Pacific did not cause the problem, yet they are amongst the world's most vulnerable to the devastating consequences. Progress on the MDGs by the Pacific is hard to imagine in a world in which greenhouse gases do not quickly peak and then stabilise at concentrations in the 350-400 ppm range.

\section{Managing the financial crisis}

In June 2009 the World Bank released its latest forecast: a decline of $2.9 \%$ in global GDP for 2009. This is the latest in a long series of forecasts that have been successively downgraded. While the impacts in the Pacific have not yet been severe, it is now becoming apparent that they have lagged behind those in the developed world. It is likely that they will continue after much of the rest of the world has started to recover.

Initial analysis reveals the obvious impacts of falling exports (less so for commodities like minerals and oil), a drop in tourism numbers, declining levels of remittances (especially affecting Samoa and Tonga), losses of income from trust funds (Tuvalu and Kiribati), exchange rate volatility and a fall in investment and the availability of credit. However, some impacts are less predictable, such as the steep decline in the balance of payments for Solomon Islands as a result of reduced timber exports.

Traditional forms of community resilience will stand the Pacific in better stead to weather the financial storm than many of the developed nations. Samoan Prime Minister Tuilaepa Sailele Lupesoliai Malielegaoi and other Pacific leaders are talking about their people going back to the basics of subsistence living, but the fragile formal economies of the Pacific are likely to suffer.

The Pacific needs its larger neighbours and the international community to manage this crisis in ways that will use this opportunity to secure coordinated international reform of financial markets and provide the financial assistance for the countries that need it, without inappropriate conditionality. The G20 countries in March 2009 promised that $1 \%$ of the world's stimulus packages would go to the world's poorest countries. Such funding could provide the impetus that the Pacific needs to invest in its infrastructure and use the economic recovery to kick-start economic development towards achievement of the MDGs.

\section{Policy coherence}

A recent report on 'policy coherence for development' (Hudson and Jonsson, 2009) identifies the need for political commitment that is translated into clear and coherent policies; policy coordination mechanisms that take account of development interests; and monitoring, analysis and reporting. The report notes that New Zealand relies on informal mechanisms that may be seen as sufficient in a small society, but which may have costs in terms of a lack of transparency and accountability.

The preceding section indicates that there are possible synergies but also potentially serious conflicts in New Zealand's policy aims related to aid, trade and climate change. It is clear that a stronger and more transparent process is urgently needed to align the range of these policies and others towards New Zealand's stated aim of supporting the Pacific's development.

\section{Conclusion}

The poorest countries in the Pacific face a difficult time ahead. There are large numbers of people living in poverty, and increasing pressures from the growing numbers of youth, lack of jobs and high levels of inequality. On a population 
basis the Pacific is seriously off track on the Millennium Development Goals. A massive effort is needed, establishing new partnerships with civil society and mobilising all groups within these countries towards common aims and improved accountabilities.

There are exciting opportunities to stimulate the types of economic development that are sustainable, inclusive and appropriate to the local context. These can build on the Pacific's strengths, recognising that the Pacific's enterprises face inherent constraints on their ability to build strong competitive positions. Improving the living standards of much of the Pacific's people will require a targeted approach, rather than chasing business growth at any cost.

Policy coherence for development is required from the Pacific's neighbours and the international community, as well as larger and more effective aid programmes. New Zealand needs to live up to its responsibility for dealing with the dangerous combinations of crises faced by the Pacific.
In particular, we need to ensure that trade negotiations support development in the Pacific without demanding new obligations for trade liberalisation; commit to the reductions in emissions that climate science demands for protection of the Pacific and its people; provide new and additional funding for the Pacific to adapt to climate change; and contribute financial support to enable the Pacific to weather the approaching financial storm.

1 Estimate of people living below national basic needs poverty lines from UNESCAP/ADB/ UNDP (2007), with 50\% estimated for Papua New Guinea by World Bank PNG (HaywardJones, 2008)

2 This analysis draws from a literature review undertaken by Voigt-Graf (2007).

3 Eight other Pacific Island nations were not included in the index: Cook Islands, Kiribati, Federated States of Micronesia, Marshall Islands, Nauru, Niue, Palau and Tuvalu.

4 However, it should be noted that income inequality statistics should be treated with caution, due to the large contribution of the subsistence economy that is not fully measured in income/consumption data.

5 NZAID's economic development assistance will contribute to three development outcomes: a reduction in the number of people living on less than a dollar a day and who live with regular hunger; an increase in the opportunities for poor people to earn an income and improve the resilience of their livelihoods; and increased sustainable growth and a reduction in the poverty faced by people living in the poorer regions of developing countries.

\section{References}

Abbott, D. and S. Pollard (2004) Hardship and Poverty in the Pacific, Manila: Asian Development Bank

AusAID (2008) Tracking Development and Governance in the Pacific, Canberra: AusAID

Baxter, M. (2001) Enclaves and Equity: the rural crisis and development choice in Papua New Guinea, Canberra: AusAID

Bazeley, P. and B. Mullen (2006) Vanuatu Economic Opportunities Fact Finding Mission: on behalf of AUSAID and NZAID, Canberra: AusAID

Braxton, N (2009) PACER Plus and its Alternatives: Which Way for Development, Oxfam New Zealand

Chang, H.-J. (2002) Kicking Away the Ladder: development strategy in historical perspective, London: Anthem Press

Coates, B. (2009) Economic Development for the People: promising directions for the Pacific's future, Oxfam New Zealand (forthcoming)

Coates, B. and S. Lennon (2005) Re-visioning Trade and Development in the Pacific, Oxfam New Zealand

Collier, P. (2007) The Bottom Billion: why the poorest countries are failing and what can be done about it, Oxford: Oxford University Press

DFID (2009) Eliminating World Poverty: building our common future, London: DFID

Global Humanitarian Forum (2009) Anatomy of a Silent Crisis, Geneva: Global Humanitarian Forum

Green, D. (2007) From Poverty to Power, Oxfam International

Hanson, F. (2009), quoted in 'China's chequebook diplomacy in Fiji under fire',
Sydney Morning Herald, 21 April

Hau'ofa, E. (1993) 'Our sea of islands', in E. Waddell, V. Naidu and E. Hauofa (eds), A New Oceania: rediscovering our sea of islands, Suva: University of the South Pacific

Hayward-Jones, J. (2008) Beyond Good Governance: shifting the paradigm for Australian aid to the Pacific Islands region, Sydney: Lowy Institute

Hudson, A. and L. Jonsson (2009) 'Beyond Aid' for Sustainable Development, London: Overseas Development Institute

Hughes, H. (2003) Aid Has Failed the Pacific, Issue Analysis 33, Centre for Independent Studies

IPCC (2007) Intergovernmental Panel on Climate Change Fourth Assessment Report: Working Group II, UNFCCC

MFAT (2009) Statement of Intent 2009-2012, Wellington: Ministry of Foreign Affairs and Trade

New Zealand Cabinet (2009), New Zealand Agency for International Development: mandate and policy settings, Wellington: Ministry of Foreign Affairs

Oxfam (2002) Rigged Rules \& Double Standards: trade globalization and the fight against poverty, Oxfam International

Oxfam (2007) Adapting to Climate Change: what's needed in poor countries and who should pay, Oxfam International

Oxfam (2008) Turning Carbon into Gold: how the international community can finance climate change adaptation without breaking the bank, Oxfam International

Oxfam New Zealand (2009) The Future is Here: climate change in the Pacific, Oxfam New Zealand
Rodrik, D. (2004) Rethinking Growth Policies in the Developing World, Cambridge, Massachusetts: Harvard University Press Rodrik, D. (2006) 'Goodbye Washington consensus, hello Washington confusion?', Journal of Economic Literature, 44, December, pp.969-83

Sen, K. (2008) Fragile States or Failed Policies: some donor-induced dilemmas, UK: International NGO Training and Research Centre (INTRAC)

Tafuna'i, A. (2007) Technology, Tradition and Trade Sustainable Rural Economies in Samoa, Apia: Women in Business Development Inc

Voigt-Graf (2007) 'Socioeconomic background: country typologies', in Skilling the Pacific: technical and vocational education and training in the Pacific, UNESCAP

UN (2005) Investing in Development, New York: UN Millennium Project

UN (2008) Millennium Development Goals Report, New York: United Nations

UNDP (2007) Human Development Report 2008

UNESCAP/ADB/UNDP (2007) The Millennium Development Goals: progress in Asia and the Pacific

Winters, A. and P. Martins (2004) 'When comparative advantage is not enough: business costs in small remote economies', World Trade Review, 3 (3), pp.347-83

World Bank (2006) The Pacific Infrastructure Challenge, Washington, DC: World Bank

World Bank (2007) Opportunities to Improve Social Services: human development in the Pacific Islands, Washington, DC: World Bank 